\title{
Seasonal optimality of high intensity physical activity for men of mature age
}

\author{
Pryshva O.B. ${ }^{\text {ABCDE }}$ \\ Kherson State University, Ukraine
}

Authors' Contribution: A - Study design; B - Data collection; C - Statistical analysis; D - Manuscript Preparation; E - Funds Collection.

\begin{abstract}
Purpose: $\quad$ To study and compare the seasonal response of men's cardiovascular system to physical activity of high intensity with average annual rates. Determine the optimal seasons for the intensification of occupations by physical activity of high intensity.

Material: $\quad$ The study was attended by men aged $40-55$ years old $(n=18)$, leading a healthy lifestyle. All men do not have chronic illnesses. All men have the experience of independent occupations of high intensity physical activity. Men live in the south of Ukraine. For 12 months, daily (after a night sleep) the body weight, heart rate, and arterial pressure were recorded. Calculated: body mass index, cardiovascular system tension. Physical activity was measured by bioresigners Basis B1, Peak.

Results: $\quad$ In winter, the overall physical activity of men was significantly lower (by $11.37 \%$ ) than the average annual. Physical activity of high intensity was lower by $21.61 \%$. In summer, the time of men's employment has significantly decreased (by $4.11 \%$ ) for the average annual. In autumn period, the total physical activity was significantly higher (4.73\%) than the average annual.

Conclusions: It was determined that the physical activity of high intensity during all seasons positively affects the physical condition of men. It reduces the tension of the cardiovascular system. It is advisable to predict the summer season as the most optimal for the intensification of the physical activity of high intensity of mature age men.

Keywords: physical activity, physical condition, men, cardiovascular system, seasonal periods, seasonality.
\end{abstract}

\section{Introduction}

Physical activity (PA) is an integral part of a valuable human life. It is difficult to overestimate the PA importance in today's urban conditions of life. The most effective is recognized PA of medium and high intensity [1, 2]. There are sufficiently substantiated recommendations of the World Health Organization regarding the number, intensity of PA during the day, week. But it is not enough to study long-standing periods - seasonal, annual. The environment changes as a result of seasonal periods, which has formed the genetic dependence of man on the environment. Lifestyle, PA of a man has changed depending on the seasonal temperature changes, the duration of light day, the amount of solar radiation. Physical activity of high intensity (PAHI) is considered to be the most significant for all age categories $[1,3,4]$. This is especially true of men. In today's living conditions men feel lack of the ability to implement PAHI. Therefore, the relevance of the PAHI's optimality research and its subsequent intensification for the physical condition (PC) of men under different seasonal conditions is becoming acute.

PAHI requires from the human body significant energy consumption and stresses of most functional systems. Therefore, the desire to practice PAHI in a person depends on its PC, due to many factors: seasonal changes, and so on. Current research proves the connection between hormonal changes in the body of people with season and seasonal temperature [5]. In winter period there is a decrease in metabolism and motor activity, in spring and summer the physiological processes are activated [6]. Seasonal (c) Pryshva O.B., 2018

doi:10.15561/18189172.2018.0307 changes in human PC are confirmed in neurohumoral processes of the body [7]. Greater tension of regulatory mechanisms, activation of the sympathetic department of the autonomic nervous system in athletes was detected in winter [8]. In June, the seasonal differences in the cardiopulmonary bypass system revealed a reduction in blood pressure (BP). In August, the lowest value is observed. In the stomach there is a further increase to the winter indexes [9]. In summer, an increase in the lung capacity is observed. In winter, an increase in the frequency of heart rate (HR) is observed at rest. This is due to the seasonal change in the autonomic regulation of the cardiovascular system (CVS) and its activities [10]. In summer, the ratio of fat in the elderly decreases, and in winter time - increases [10]. In winter, athletes found a relatively low level of physical capacity, the maximum increase in heart rate. In summer, a minimum increase in heart rate was established. This is due to an increase in physical activity [11]. In summer, athletes experienced a lower oxygen cost. This indicates a higher reserve capacity of the cardiopulmonary resuscitation system [11].

Seasonal differences in general PA of teenagers were found in a large majority of studies [12, 13, 14]. The decrease of children's PA in Japan is due to rising summer temperatures [15]. It was established that during the year (pedometers) PA in people of mature age in summer was greater than in winter. The number of steps was 6509, $20 \%$ of them are aerobic steps (more than 100 steps per minute) [16]. In the group of adults with normal body mass index (BMI), there was a decrease in the number of steps in winter compared to summer [17]. Similar data was obtained from elderly people, in whom PA was 
the lowest in winter. PA reached the maximum number of steps in spring and autumn. The number of steps in summer corresponded to the average annual level [18]. The decrease in the duration of PA was noted in summer and winter. The speed of steps increased in winter [10]. Other studies [19] found that men with normal physical conditions had significantly higher seasonal differences in PA than men with intense adaptive CVS processes. At the same time, not all researchers are unanimous in seasonal changes of PA. The studies of Wang G et al [20] did not reveal significant seasonal differences of PA of low-middle-aged male adults (Beijing residents). PAHI was found to be significantly higher in spring than in other seasons. In spring Swedes spent more time on PAHI than in autumn [21].

The research of the problems of prognostic possibilities of PA of men on the eve of PAHI has allowed to establish differences in readiness of an organism for physical activity. These facts may be related to seasonal influences. In spring, men expressed a desire to engage in PAHI at a day when the CVS was more intense (by $3.09 \%$ ) comparing with the previous day [22]. In summer, the intensity of the CVS increased to 3.29\% [23], in autumn - up to $4.58 \%$ [24]. In winter, the desire to attend classes arose with an increase in tension to 5.25\% [25]. It is anticipated that longer PAHI studies in different seasons will enable them to intensify and rationally plan them throughout the year.

The aim of the study. To study and compare seasonal physical activity of high intensity, physical condition of men of mature age with average annual indices. Also, determine the most optimal seasons for the intensification of PAHI classes.

\section{Material and Methods.}

Participants: in the study participated men aged 4055 years old $(n=18)$, leading a healthy lifestyle without chronic diseases. All men have experience of independent PAHI classes. Men live in the south of Ukraine.

Organization of the study: The observation was conducted within 12 months. In the experiment participants conducted an ordinary way of life. Physical activity of high intensity (running, sports games) was carried out individually on request. Every day in the morning they recorded: body weight, heart rate, blood pressure. Used automatic tonometer Contec-08A. Daily physical activity was recorded on the number of steps passed, time of physical activity. Weekly physical activity of high intensity was recorded (heart rate higher than 140 beats/ min,) in number of steps, time of classes. Bioresigners Basis B1, Basis Peak were used. For weekly reports of participants and results of bioregistrators, we calculated: $\mathrm{BMI}$; the tension of the cardiovascular system (according to the adaptive potential of Baevskyi) [26]. The results were investigated: at the days of PAHI by season; the next day by season; total per season; total per year. APB was calculated in absolute units (a.u.) by the formula:

$\mathrm{APB}=0.0 \cdot \mathrm{HR}+0.014 \cdot \mathrm{ABP}+0.008 \cdot \mathrm{APD}+0.014 \cdot \mathrm{Age}+0$. $009 \cdot \mathrm{BW}, 009 \cdot \mathrm{BL}-0.273$, where, $H R$ - heart rate in rest (bpm); ABP - arterial pressure systolic, (mm Hg); DBP - APD - arterial pressure diastolic, (mm Hg); BW - body weight, (kg); BL - bode length, $(\mathrm{cm})$; age - age of the subject, (years). Percentages were calculated using the formula $x=(b-a): a * 100 \%$ where, $x$ is the percentage value; $a$ is a previous indicator, $b$ is the next indicator of a comparable pair of numbers.

Statistical analysis: calculations were carried out using nonparametric statistics, since the results did not match the normal distribution. Defined: $95 \%$ interquartile scale (IS), median (Me). Comparison of the indicators was carried out using Wilcoxon Signed Rank Criteria with Reliability $(p=0,05)$. Excel and Statgraphics16 were used.

\section{Results}

Investigation of the seasonal inclination of men to PAHI classes allowed to reveal their physical condition, PAHI and the physical condition reaction to PAHI. Considered the physical state of the whole. Also, the physical condition of PAHI at day was considered, which induced them to such a load. Physical activity characteristics were defined: number of steps, PAHI occupation time, body reaction to the received physical activity of the next day. Data from each season were compared with the average annual. Comparative analysis of indicators of physical condition and physical activity of men in winter (Table 1) showed a slight excess of their weight. The absence of significant differences in BMI in men was observed throughout all seasons. The total physical activity of men (the number of steps per day) was less than the annual. The number of PAHI steps per week and lessons were less than the average annual. Total physical activity, PAHI and training time of PAHI were less than those recommended by the World Health Organization in all seasons.

The physical condition of men was investigated by the intensity of the cardiovascular system and recorded in the complex index of APB. In winter, the daily state of the cardiovascular system, the state of the day and the following day PAHI - were more intense than the average annual. The tension in the cardiovascular system of men in all seasons does not exceed the maximum age limits.

In spring, a comparative analysis of the physical condition and physical activity indicators of men (Table 2) highlighted the following seasonal peculiarities: total physical activity, PAHI and PAHI classes increased and became larger than the average annual.

The daily state of cardiovascular tension, at the day of PAHI and the day after PAHI, has declined. It does not differ significantly from the average annual.

In summer period (Table 3), the daily overall physical activity of men and PAHI did not differ significantly from the average annual. Time of PAHI was less than average.

The daily condition of the cardiovascular system, at the day of PAHI and the next day after PAHI has decreased. It was less tense than the average.

In autumn period, the daily physical activity increased and exceeded the average annual. PAHI and its time have decreased. They became smaller than the average annual.

The daily tension of the cardiovascular system at the 
Table 1. Comparison of indicators of physical condition and physical activity of men in winter

\begin{tabular}{|c|c|c|c|c|c|}
\hline \multirow[t]{2}{*}{ № } & \multirow[t]{2}{*}{ Name of index } & \multirow{2}{*}{$\begin{array}{l}\text { Winter period } \\
\text { Me } \\
(95 \% \mathrm{IS}) \\
(n=1583)\end{array}$} & \multirow{2}{*}{$\begin{array}{l}\text { Per year } \\
\text { Me } \\
(95 \% I S) \\
(n=6425)\end{array}$} & \multirow[t]{2}{*}{$\%$} & \multirow[t]{2}{*}{$\begin{array}{l}W \\
\text { (p) }\end{array}$} \\
\hline & & & & & \\
\hline & $\mathrm{BMI}\left(\mathrm{kg} / \mathrm{m}^{2}\right)$ & $\begin{array}{l}27,94 \\
(25,62 ; 30,26)\end{array}$ & $\begin{array}{l}27,57 \\
(25,41 ; 29,73)\end{array}$ & $-1,35$ & $>0,05$ \\
\hline & $\begin{array}{l}\text { General physical activity (steps/ } \\
\text { day) }\end{array}$ & $\begin{array}{l}5922,56 \\
(4268,17 ; \\
7576,95)\end{array}$ & $\begin{array}{l}6594,35 \\
(4035,63 \\
9153,07)\end{array}$ & 11,37 & $<0,05$ \\
\hline & \multirow[t]{2}{*}{ Absolute units (a.u.) } & $\begin{array}{l}1,67 \\
(1,57 ; 1,79)\end{array}$ & $\begin{array}{l}1,60 \\
(1,49 ; 1,71)\end{array}$ & $-4,21$ & $<0,05$ \\
\hline & & $(n=370)$ & $(n=1695)$ & & \\
\hline & PAHI (steps/week) & $\begin{array}{l}1674,21 \\
(734,28 ; \\
2614,15)\end{array}$ & $\begin{array}{l}2035,28 \\
(927,31 \\
3143,25)\end{array}$ & 21,61 & $<0,05$ \\
\hline & Time of PAHI (min/week) & $\begin{array}{l}11,75 \\
(6,41 ; 17,08)\end{array}$ & $\begin{array}{l}12,77 \\
(7,18 ; 18,36)\end{array}$ & 8,67 & $<0,05$ \\
\hline & APB at the day of PAHI (a.u.) & $\begin{array}{l}1,69 \\
(1,52 ; 1,86)\end{array}$ & $\begin{array}{l}1,63 \\
(1,47 ; 1,79)\end{array}$ & $-3,75$ & $<0,05$ \\
\hline & APB next day after the PAHI (a.u.) & $\begin{array}{l}1,61 \\
(1,49 ; 1,70)\end{array}$ & $\begin{array}{l}1,54 \\
(1,45 ; 1,63)\end{array}$ & $-4,48$ & $<0,05$ \\
\hline
\end{tabular}

Note: APB - Adaptive Potential of Baevskyi; IS - Interquartile scale; W - Wilcoxon Signed Rank Criteria; (p) - value of reliability; Me - the median.

Table 2. Comparison of indicators of physical condition and physical activity of men in spring

\begin{tabular}{|c|c|c|c|c|c|}
\hline \multirow[t]{2}{*}{ № } & \multirow[t]{2}{*}{ Name of index } & \multirow{2}{*}{$\begin{array}{l}\text { Winter period } \\
\text { Me } \\
(95 \% I S) \\
(n=1615)\end{array}$} & \multirow{2}{*}{$\begin{array}{l}\text { Per year } \\
\text { Me } \\
(95 \% \text { IS) } \\
(n=6425)\end{array}$} & \multirow[t]{2}{*}{$\%$} & \multirow[t]{2}{*}{$\begin{array}{l}W \\
(p)\end{array}$} \\
\hline & & & & & \\
\hline & $\mathrm{BMI}\left(\mathrm{kg} / \mathrm{m}^{2}\right)$ & $\begin{array}{l}28,06 \\
(25,47 ; 30,65)\end{array}$ & $\begin{array}{l}27,57 \\
(25,41 ; 29,73)\end{array}$ & $-1,71$ & $>0,05$ \\
\hline & $\begin{array}{l}\text { General physical activity (steps/ } \\
\text { day) }\end{array}$ & $\begin{array}{l}6907,37 \\
(4791,36 ; \\
9023,38)\end{array}$ & $\begin{array}{l}6594,35 \\
(4035,63 ; \\
9153,07)\end{array}$ & $-4,56$ & $<0,05$ \\
\hline & \multirow[t]{2}{*}{ APB (a.u.) } & $\begin{array}{l}1,65 \\
(1,51 ; 1,79)\end{array}$ & $\begin{array}{l}1,60 \\
(1,49 ; 1,71)\end{array}$ & $-3,03$ & $>0,05$ \\
\hline & & & $(n=1695)$ & & \\
\hline & PAHI (steps/week) & $\begin{array}{l}2501,76 \\
(1628,35 \\
3375,17)\end{array}$ & $\begin{array}{l}2035,28 \\
(927,31 ; \\
3143,25)\end{array}$ & $-18,67$ & $<0,05$ \\
\hline & Time of PAHI (min/week) & $\begin{array}{l}15,27 \\
(11,24 ; 19,3)\end{array}$ & $\begin{array}{l}12,77 \\
(7,18 ; 18,36)\end{array}$ & $-16,39$ & $<0,05$ \\
\hline & APB at the day of PAHI (a.u.) & $\begin{array}{l}1,67 \\
(1,53 ; 1,81)\end{array}$ & $\begin{array}{l}1,63 \\
(1,47 ; 1,79)\end{array}$ & $-2,45$ & $>0,05$ \\
\hline & APB next day after the PAHI (a.u.) & $\begin{array}{l}1,59 \\
(1,47 ; 1,71)\end{array}$ & $\begin{array}{l}1,54 \\
(1,45 ; 1,63)\end{array}$ & $-3,08$ & $>0,05$ \\
\hline
\end{tabular}


Table 3. Comparison of indicators of physical condition and physical activity of men in summer

\begin{tabular}{|c|c|c|c|c|c|}
\hline \multirow[t]{2}{*}{ № } & \multirow[t]{2}{*}{ Name of index } & $\begin{array}{l}\text { Summer period } \\
(n=1622) \\
\text { Me } \\
(95 \% I S)\end{array}$ & $\begin{array}{l}\text { Per year } \\
\text { Me } \\
\text { (95\%IS) }\end{array}$ & \multirow[t]{2}{*}{$\%$} & \multirow[t]{2}{*}{$\begin{array}{l}W \\
(p)\end{array}$} \\
\hline & & $(n=1622)$ & $(n=6425)$ & & \\
\hline & $\mathrm{BMI}\left(\mathrm{kg} / \mathrm{m}^{2}\right)$ & $\begin{array}{l}27,08 \\
(25,02 ; 29,14)\end{array}$ & $\begin{array}{l}27,57 \\
(25,41 ; 29,73)\end{array}$ & 1,84 & $>0,05$ \\
\hline & $\begin{array}{l}\text { General physical activity (steps/ } \\
\text { day) }\end{array}$ & $\begin{array}{l}6623,41 \\
(4418,94 ; 8827,87)\end{array}$ & $\begin{array}{l}6594,35 \\
(4035,63 ; 9153,07)\end{array}$ & $-0,46$ & $>0,05$ \\
\hline & \multirow[t]{2}{*}{ APB (a.u.) } & $\begin{array}{l}1,52 \\
(1,45 ; 1,59)\end{array}$ & $\begin{array}{l}1,60 \\
(1,49 ; 1,71)\end{array}$ & 4,99 & $<0,05$ \\
\hline & & & $(n=1695)$ & & \\
\hline & PAHI (steps/week) & $\begin{array}{l}2027,65 \\
(1259,38 ; 2795,92)\end{array}$ & $\begin{array}{l}2035,28 \\
(927,31 ; 3143,25)\end{array}$ & 0,37 & $>0,05$ \\
\hline & Time of PAHI (min/week) & $\begin{array}{l}12,03 \\
(9,04 ; 15,02)\end{array}$ & $\begin{array}{l}12,77 \\
(7,18 ; 18,36)\end{array}$ & 4,11 & $<0,05$ \\
\hline & APB at the day of PAHI (a.u.) & $\begin{array}{l}1,55 \\
(1,42 ; 1,68)\end{array}$ & $\begin{array}{l}1,63 \\
(1,47 ; 1,79)\end{array}$ & 5,24 & $<0,05$ \\
\hline & $\begin{array}{l}\text { APB next day after the PAHI } \\
\text { (a.u.) }\end{array}$ & $\begin{array}{l}1,43 \\
(1,34 ; 1,52)\end{array}$ & $\begin{array}{l}1,54 \\
(1,45 ; 1,63)\end{array}$ & 7,76 & $<0,05$ \\
\hline
\end{tabular}

Table 4. Comparison of indicators of physical condition and physical activity of men in autumn period

\begin{tabular}{|c|c|c|c|c|c|}
\hline \multirow[t]{2}{*}{ № } & \multirow[t]{2}{*}{ Name of index } & \multirow{2}{*}{$\begin{array}{l}\text { Autumn period } \\
\text { Me } \\
\text { (95\%IS) } \\
(n=1605)\end{array}$} & \multirow{2}{*}{$\begin{array}{l}\text { Per year } \\
\text { Me } \\
(95 \% \text { IS }) \\
(n=6425)\end{array}$} & \multirow[t]{2}{*}{$\%$} & \multirow[t]{2}{*}{$\begin{array}{l}W \\
\text { (p) }\end{array}$} \\
\hline & & & & & \\
\hline & $\mathrm{BMI}\left(\mathrm{kg} / \mathrm{m}^{2}\right)$ & $\begin{array}{l}27,35 \\
(25,17 \\
29,53)\end{array}$ & $\begin{array}{l}27,57 \\
(25,41 ; \\
29,73)\end{array}$ & 0,85 & $>0,05$ \\
\hline & General physical activity (steps/day) & $\begin{array}{l}6924,07 \\
(4135,27 ; \\
9712,87)\end{array}$ & $\begin{array}{l}6594,35 \\
(4035,63 ; \\
9153,07)\end{array}$ & $-4,73$ & $<0,05$ \\
\hline & \multirow[t]{2}{*}{ APB (a.u.) } & $\begin{array}{l}1,56 \\
(1,46 ; 1,66)\end{array}$ & $\begin{array}{l}1,60 \\
(1,49 ; 1,71)\end{array}$ & 2,46 & $>0,05$ \\
\hline & & & $(n=1695)$ & & \\
\hline & PAHI (steps/week) & $\begin{array}{l}1937,41 \\
(1174,37 ; \\
2700,45)\end{array}$ & $\begin{array}{l}2035,28 \\
(927,31 ; \\
3143,25)\end{array}$ & 5,09 & $<0,05$ \\
\hline & Time of PAHI (min/week) & $\begin{array}{l}12,18 \\
(8,42 ; 15,94)\end{array}$ & $\begin{array}{l}12,77 \\
(7,18 ; 18,36)\end{array}$ & 4,89 & $<0,05$ \\
\hline & APB at the day of PAHI (a.u.) & $\begin{array}{l}1,59 \\
(1,47 ; 1,71)\end{array}$ & $\begin{array}{l}1,63 \\
(1,47 ; 1,79)\end{array}$ & 2,51 & $>0,05$ \\
\hline & APB next day after the PAHI (a.u.) & $\begin{array}{l}1,51 \\
(1,41 ; 1,60)\end{array}$ & $\begin{array}{l}1,54 \\
(1,45 ; 1,63)\end{array}$ & 1,85 & $>0,05$ \\
\hline
\end{tabular}


Table 5. Comparison of APB indices of the next day after PAHI with men's daily indicators in seasonal periods

\begin{tabular}{|c|c|c|c|c|c|}
\hline № & Name of index & $\begin{array}{l}\text { APB next day of PAHI } \\
\text { (a.u.) } \\
\text { Me } \\
(95 \% \mathrm{IS})\end{array}$ & $\begin{array}{l}\text { Daily APB (a.u.) } \\
\text { Me } \\
\text { (95\%IS) }\end{array}$ & $\%$ & $\begin{array}{l}W \\
\text { (p) }\end{array}$ \\
\hline & Winter & $\begin{array}{l}1,61 \\
(1,45 ; 1,63)\end{array}$ & $\begin{array}{l}1,67 \\
(1,57 ; 1,79)\end{array}$ & $-3,70$ & $<0,05$ \\
\hline & Spring & $\begin{array}{l}1,59 \\
(1,47 ; 1,71)\end{array}$ & $\begin{array}{l}1,65 \\
(1,51 ; 1,79)\end{array}$ & $-3,63$ & $<0,05$ \\
\hline & Summer & $\begin{array}{l}1,42 \\
(1,34 ; 1,52)\end{array}$ & $\begin{array}{l}1,52 \\
(1,45 ; 1,59)\end{array}$ & $-6,23$ & $<0,05$ \\
\hline & Autumn & $\begin{array}{l}1,51 \\
(1,41 ; 1,60)\end{array}$ & $\begin{array}{l}1,56 \\
(1,46 ; 1,66)\end{array}$ & $-3,14$ & $<0,05$ \\
\hline
\end{tabular}

Table 6. Comparison of APB indices of the next day after PAHI with the indicators on the day of men's employment, in seasonal periods

\begin{tabular}{|c|c|c|c|c|c|}
\hline № & Name of index & $\begin{array}{l}\text { APB next day of PAHI } \\
\text { (a.u.) } \\
\text { Me } \\
(95 \% \text { IS) }\end{array}$ & $\begin{array}{l}\text { APB at the day of PAHI } \\
\text { (a.u.) } \\
\text { Me } \\
\text { (95\%IS) }\end{array}$ & $\%$ & $\begin{array}{l}W \\
(p)\end{array}$ \\
\hline & Winter & $\begin{array}{l}1,61 \\
(1,45 ; 1,63)\end{array}$ & $\begin{array}{l}1,69 \\
(1,52 ; 1,86)\end{array}$ & $-4,84$ & $<0,05$ \\
\hline & Spring & $\begin{array}{l}1,59 \\
(1,47 ; 1,71)\end{array}$ & $\begin{array}{l}1,67 \\
(1,53 ; 1,81)\end{array}$ & $-4,73$ & $<0,05$ \\
\hline & Summer & $\begin{array}{l}1,42 \\
(1,34 ; 1,52)\end{array}$ & $\begin{array}{l}1,54 \\
(1,42 ; 1,68)\end{array}$ & $-7,75$ & $<0,05$ \\
\hline & Autumn & $\begin{array}{l}1,51 \\
(1,40 ; 1,60)\end{array}$ & $\begin{array}{l}1,59 \\
(1,47 ; 1,71)\end{array}$ & $-4,91$ & $<0,05$ \\
\hline
\end{tabular}

day of PAHI and the next day did not have a significant difference with the average yearly.

We compared the intensity of the cardiovascular system the next day after physical activity with daily values (Table 5).

In all periods (the day after PAHI), intensity of the cardiovascular system has significantly decreased. The greatest decline was recorded in summer.

It was compared the intensity of the cardiovascular system the day after day with PAHI (Table 6). There is a decrease in tension throughout the seasons. The largest decrease is recorded in summer.

\section{Discussion.}

The results of the BMI of men have ambiguous results. The absence of significant seasonal variations with the average year is consistent with studies by Wang Guanlin et al. [20]. This result is not confirmed by Nakayama et al. [10] on the seasonal change in the percentage of fat in the elderly. Probably because of different comparison techniques. Nakayama et al. [10] compared winter performance with the elderly. Our data for each season was compared to the average annual.

The growth of general physical activity of men in spring, fall and winter decline correlates with the study of PA in teenagers [15]. These data extend research with the population of mature [16,27] and elderly [10, 17]. Equality of the number of steps of general physical activity in summer to the average year is consistent with the data of the research of the elderly [18]. However, Wang Guanlin et al. [20] did not reveal seasonal differences in PA in the urban population. Perhaps because of the dominant urbanistic rhythm of people's lives.

Confirmed positive influence of PAHI on the physical condition of a person [1]. Other studies [22, 25] on PAHI changes in men during winter and spring periods have also been expanded. Their dynamics are similar to general physical activity. Other results [24] confirmed and augmented by autumn dynamics of PAHI of male. These dynamics showed a decrease in the number of steps in relation to the average annual. General physical activity was higher than average.

The seasonal changes in the physical condition of males became consistent $[6,7,9]$. On a daily basis, the tensile stress of men's CVS grew in winter and declined in summer. Men's results in reducing the number of PAHI steps in winter and their increasing in spring is consistent with studies by Hagströmer et al. [21].

Extended data from another study [23]: the identity of the number of steps of men in summer to the average year. It is noteworthy that the spent time at PAHI in summer was significantly lower than the average annual (with the same amount of passed steps). This may indicate higher intensity of PA. More broadly, the more frequent readiness 
of the male body to PAHI in summer is highlighted. The difference in APB at the day of PAHI from the previous day was insignificant.

For the first time, the seasonal differences of the CVS at the day of PAHI were revealed. They testify to the different levels of body readiness for this type of load. Its increasing in winter period involves greater tension of the CVS. These data extend the findings of another study [25] on the significant difference between the day before and at the day of PAHI classes.

For the first time, seasonal differences were found in the resumption of men's CVS the day after PAHI. The low restoration of the CVS was recorded in winter and high in summer. That also broadens the study data $[8,11]$ on the seasonal characteristics of the cardiopulmonary bypass system of athletes.

It can be argued about the influence of the factor of seasonal reaction of men on PAHI.

\section{Conclusions.}

A different seasonal response of the physical condition of men at the day of PAHI studies and its restoration of the next day is revealed. It was found that in winter men were engaged in PAHI with a more intense initial state of the cardiovascular system than the average age. In summer, the state of the cardiovascular system was less intense than the average year. In winter, the restoration of the cardiovascular system of men the next day after PAHI was worse than the average annual, and in summer - the best. It was found that PAHI during all seasons positively affects the physical condition of men. This reduces the tension of the cardiovascular system. It is advisable to foresee the summer season as the most optimal for the intensification of PAHI of men of mature age.

\section{Conflict of interest.}

The author states that there is no conflict of interest.

\section{References}

1. Gebel K, Ding D, Chey T. Effect of moderate to vigorous physical activity on all-cause mortality in middle-aged and older Australians. JAMA Intern Med. 2015;(175):970-7.

2. Bobro O, Nedelev S. Possibility of using general medical knowledge by students majoring in physical training. Science and Education. 2016(4):111-116.

3. Carson V, Tremblay MS, Chaput J-P, Chastin SFM. Associations between sleep duration, sedentary time, physical activity, and health indicators among Canadian children and youth using compositional analyses. Applied Physiology, Nutrition, and Metabolism, 2016;41:S294-302. doi:10.1139/apnm-2016-0026

4. Khoroshukha M, Levytska L, Omelchuk O. Quick test of assessing somatic health of people with musculoskeletal disorders. Science and Education. 2016(8):169-175.

5. Gullo D, Latina A, Frasca F, Squatrito S, Belfiore A, Vigneri R. Seasonal variations in TSH serum levels in athyreotic patients under L-thyroxine replacement monotherapy. Clinical Endocrinology, 2017;87:207-15. doi:10.1111/ cen.13351

6. Komarov FI. Chronobiology and chronomedicine. Triada-X; 2000. (in Russian)

7. Zakharchuk OI, Pishak VP, Krivchans'ka MI. Biological rhythms and sleep. Naukovij visnik Uzhgorods'kogo universitetu, 2013;(2):47-52. (in Ukrainian)

8. Agadzhanian MO, Polatajko IuO. Features of the reaction of the cardiorespiratory system of athletes-swimmers to the action of hypoxia in different seasons of the year. Visnik Prikarpats'kogo universitetu, 2013; (18):59-63. (in Ukrainian)

9. Verdon F, Jacot E, Boudry JF. Seasonal variations of blood pressure in normal subjects and patients with chronic disease. Arch Mal Coeur Vaiss. 1997;90(9):1239-46.

10.Nakayama E, Kimura T, Kobayashi H, Kakihana W. Effects of continuous intervention for physical activity and walking for healthy older persons. Int J Nurs Clin Pract. 2015;2:133139.

11.Polatajko Iu. Influence of physical activity of maximum power on reactivity of cardiorespiratory system in athletes. Fizichne vikhovannia, sport i kul'tura zdorov'ia $u$ suchasnomu suspil'stvi, 2012;(3):19-24. (in Ukrainian)
12.Carson V, Spence JC. Seasonal variation in physical activity among children and adolescents: a review. Pediatr Exerc Sci. 2010; 22:81-92.

13.Chopyk T, Pavliuk O, Pavliuk Y. Model of future coachesteachers' professional competence formation in terms of higher educational institution. Science and Education. 2017(10):5-12. doi:10.24195/2414-4665-2017-10-1

14.Dzhurynskyi P, Burdiuzha S. Pedagogical aspects of preparing future physical culture teachers for physical recreation activities. Science and Education. 2016(10):4551.

15.Tanaka C, Reilly JJ, Tanaka M, Tanaka S. Seasonal changes in objectively measured sedentary behavior and physical activity in Japanese primary school children. BMC Public Health, 2016;16. doi:10.1186/s12889-016-3633-5

16.Carr LJ, Dunsinger S, Marcus BH. Long-term Surveillance of Physical Activity Habits of Latinas Enrolled in a 12-Month Physical Activity Intervention. Journal of Physical Activity and Health, 2016;13:740-6. doi:10.1123/jpah.2015-0482

17.Clemens SA, Hamilton SL, Griffiths PL. Summer to winter variability in the step counts of normal weight and overweight adults living in the UK. J Phys Act Health. 2011;(8):36-44.

18. Yasunaga A, Togo F, Watanabe E, Park H. Sex, age, season, and habitual physical activity of older Japanese: the Nakanojo study. J Aging Phys Act. 2008;(16): 3-13.

19.Prushva O.B. Season physical functioning dynamic of men with different physical condition. Pedagogics Psychology, 2015; ( 6): 56-9.

20.Wang G, Li B, Zhang X, Niu C, Li J, Li L, et al. No seasonal variation in physical activity of Han Chinese living in Beijing. International Journal of Behavioral Nutrition and Physical Activity, 2017;14. doi:10.1186/s12966-017-0503-1

21.Hagströmer M, Rizzo NS, Sjöström M. Associations of season and region on objectively assessed physical activity and sedentary behaviour. J Sport Sci. 2014;32(7):629-34.

22.Pryshva O.B. Planning physical activity in the spring for men on the basis of their physical condition. Slobozhans'kij naukovo-sportivnij visnik, 2016;(2):91-6. (in Ukrainian)

23.Pryshva O.B. Markers of the physical state of men of mature age in high intensity physical activity during the summer season. Fizichne vikhovannia, sport i kul'tura zdorov'ia u suchasnomu suspil'stvi, 2016; (1): 69-75. (in Ukrainian)

24.Pryshva O.B. Influence of the state of the cardiovascular 
system of men of mature age on their physical activity during the autumn period. Fizichne vikhovannia, sport i kul'tura zdorov'ia u suchasnomu suspil'stvi, 2016; 2 (34): 38-45. (in Ukrainian)

25.Tsos A., Pryshva O. Interconnection of a Physical Activity of Mature Males with Their Diet. Research Journal of
Pharmaceutical, Biological and Chemical Sciences, 2016;6(7):14-20.

26.Baevskij RM. Donosological diagnostics in the assessment of health status. Science; 1993. (in Russian)

27.Melnyk A, Chernii V. Forming physical culture teachers' motivation to study. Science and Education. 2017(8):150156. doi:10.24195/2414-4665-2017-8-22

\section{Information about the author:}

Pryshva O.B.; http://orcid.org/0000-0002-3727-5142; 00obc@yahoo.com; Kherson State University; Universytetska str. 27, Kherson, 76003, Ukraine.

Cite this article as: Pryshva OB. Seasonal optimality of high intensity physical activity for men of mature age. Pedagogics, psychology, medical-biological problems of physical training and sports, 2018;22(3):156-162. doi:10.15561/18189172.2018.0307 The electronic version of this article is the complete one and can be found online at: http://www.sportpedagogy.org.ua/index.php/PPS/issue/archive

This is an Open Access article distributed under the terms of the Creative Commons Attribution License, which permits unrestricted use, distribution, and reproduction in any medium, provided the original work is properly cited (http://creativecommons.org/licenses/by/4.0/deed.en).

Received: 28.12.2017

Accepted: 25.01.2018; Published: 30.06.2018 